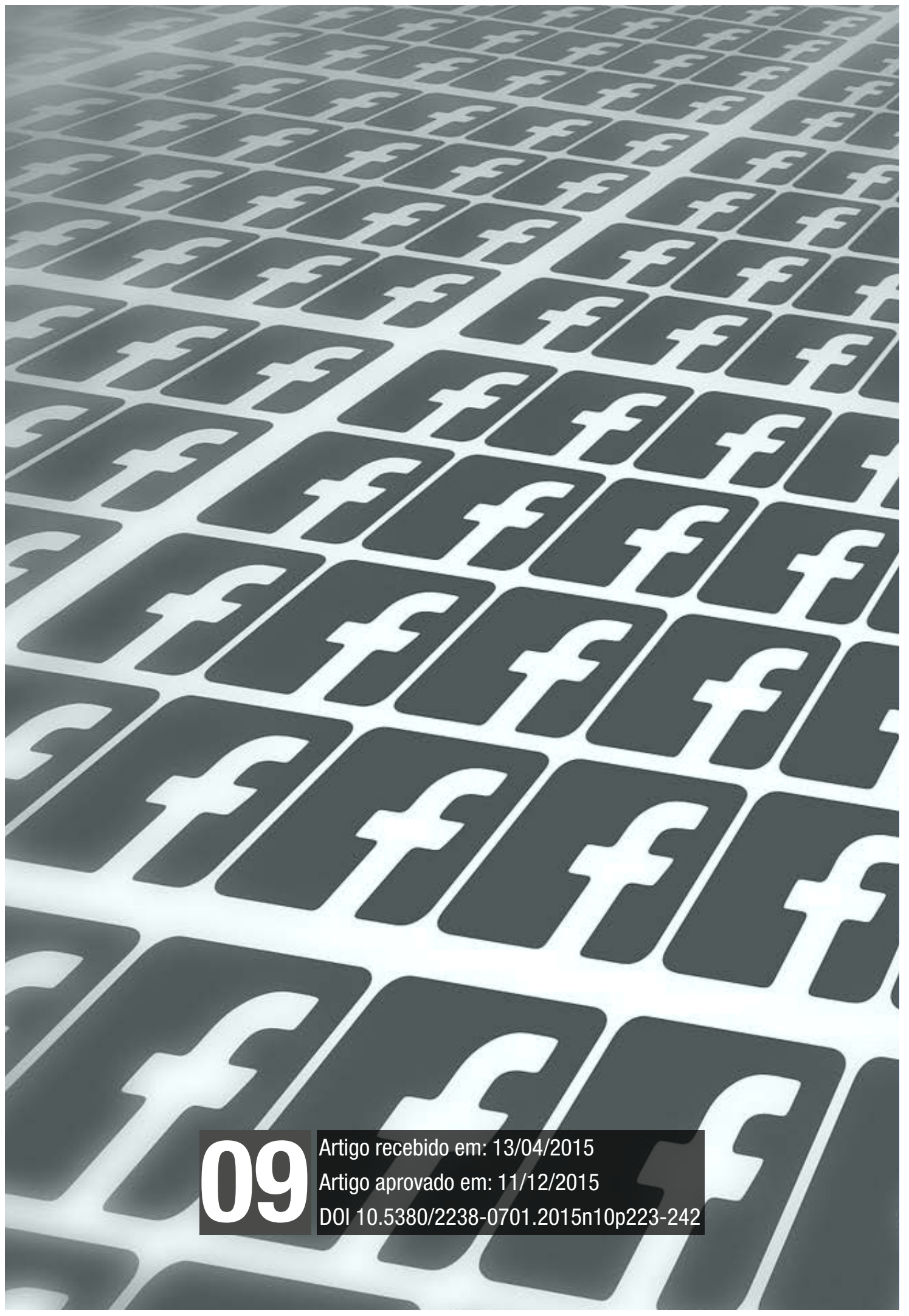


AÇÃO MIDIÁTICA, n. 10. Ju/Dez. 2015. Curitiba. PPGCOM-UFPR. ISSN 2238-0701

224 


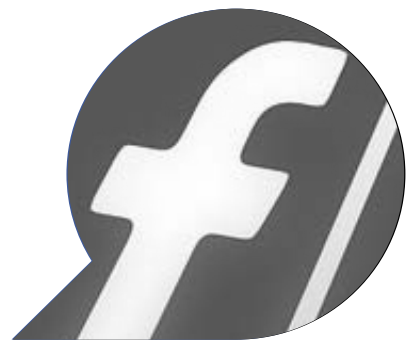

\title{
Política e afeto no tempo das redes: ou a catarse coletiva - uma análise da Mídia Ninja
}

\author{
Policy and affection in the network time: \\ or collective catharsis - an analysis of Ninja Media
}

\author{
Política y afecto en el tiempo de la red: \\ o catarsis colectiva - un análisis de Ninja Medios
}

\section{RENATA REZENDE *}

Resumo: $\mathrm{O}$ artigo analisa o engajamento político nas redes sociais da Internet, particularmente no perfil Ninja - Narrativas Independentes, Jornalismo e Ação, no Facebook, - criado durante os protestos no Brasil, em 2013. Trata-se de um recorte que pertence a uma pesquisa ampliada, cujo objetivo é verificar a produção de sentidos na construção dos relatos dos usuários dessa rede, enquanto tessitura narrativa, bem como demonstrar como se configura e opera uma política de afetos como uma catarse coletiva, nas quais as interações evidenciam

\footnotetext{
* Professora do Departamento de Comunicação e do Programa de Pós-Graduação em Mídia e Cotidiano da Universidade Federal Fluminense. Pós-Doutora em Comunicação e Cultura, Doutora em Comunicação e Mestre em Comunicação e Imagem. Jornalista com especialidade em Audiovisual e Multimídia. Pesquisadora do Multis - Núcleo de Estudos do Audiovisual no Contexto Multimídia. Coordenadora do Laboratório de Experimentos Audiovisuais (www.lea.uff. br). E-mail: renatarezender@yahoo.com.br
} 
outras possibilidades de produção e difusão informativas. Em um estudo exploratório do objeto, principalmente por meio de pesquisa bibliográfica e documental, tomamos os conceitos de catarse e política, a partir de Aristóteles, e afeto, a partir de Spinoza.

Palavras-chave: Redes sociais; Narrativas; Catarse; Afeto; Política;

Abstract: The article analyzes the political engagement in social networking sites, particularly in profile Ninja - Independent Narratives, Journalism and Action on Facebook, created during protests in Brazil in 2013. This is a part that belongs to a larger research whose aim is to verify the production of meaning in the construction of the accounts of users that network, while weaving narrative, as well as demonstrating how to set up and operate a policy of affections that operates as a collective catharsis, in which the interactions show other possibilities of production and broadcast informative. In an exploratory study of the object, primarily through bibliographical and documentary research, we take the concept of catharsis and politics, from Aristotle and affection from Spinoza.

Keywords: Sociales networks; Narrative; Catharsis; Affection; Policy;

Resumen: El artículo analiza la participación política en los sitios de redes sociales, sobre todo en el perfil de Ninja - Narrativas Independientes, Periodismo y Acción, en Facebook, creado durante las protestas en Brasil, en 2013. La pesquisa pertenece a una investigación más amplia, cuyo propósito es verificar la producción de sentido en la red, mientras que el tejido narrativo, así como demostrar los ajustes y una política de afecciones, a partir de una catarsis colectiva, y que las interacciones muestran otras posibilidades de producción e información. En un estudio exploratorio del objeto, principalmente a través de la investigación bibliográfica y documental, tomamos el concepto de catarsis y la política, de Aristóteles y el afecto de Spinoza.

Palabras Clave: Redes sociales; Narrativa; Catarsis; Afecto; Política; 


\section{Introdução}

No início do século XXI, os processos, os meios e as práticas cotidianas são cada vez mais atravessados pela interferência dos dispositivos comunicacionais, instaurando um movimento ampliado de fusão da vida cotidiana com a tecnologia, no qual se torna evidente a hibridização da techné com a aisthesis, numa conversão da vida em emoção (SODRÉ, 2006). As tecnologias de informação, de comunicação e de imagem conduzem os sujeitos à afetação da experiência pela própria tecnologia, fazendo-os viver em novas configurações humanas do modo produtivo e em novas possibilidades de organização dos meios, nas quais se exige uma dimensão que adentra mais o sensível do que o racional. Formas tradicionais de representação da realidade passaram a interagir com as novas (o virtual, o espaço simulado ou telerreal), expandindo a dimensão tecnocultural e constituindo novos sujeitos sociais.

A atual estrutura social está ligada ao surgimento de um novo modo de desenvolvimento que despontou ainda no século XX, o informacionalismo, formatado pela transformação do modo capitalista de produção. De acordo com Castells (1999), a teoria que fundamenta tal abordagem afirma que as sociedades são organizadas em processos formados por relações historicamente de produção, experiência e poder. Um novo sistema de informação que integra a produção e a distribuição de palavras, sons e imagens de nossa cultura, personalizando-os ao gosto das identidades dos indivíduos, cria novas formas e canais de comunicação, moldando a vida e sendo moldado por ela.

A aceleração do processo circulatório dos produtos informacionais (culturais) tem-se chamado de comunicação, segundo Sodré (2002, p. 15), "nome de velha cepa que antes designava uma outra ideia: a vinculação social ou o ser-em-comum, problematizado pela dialética platônica, pela koinonia politiké aristotélica e, ao longo dos tempos, pela palavra comunidade". Sodré (2002) explica que dessa perspectiva parte-se a comunicação de que hoje se fala, mas devemos levar em conta que não se trata exatamente da mesma coisa: a comunicação agora integra o plano sistêmico da estrutura de poder. $\mathrm{O}$ que significa uma redefinição do espaço público em face das mudanças estruturais (que deslocou o Estado liberal clássico), que passou a atuar em termos de influência ou poder na construção da realidade social, moldando percepções, afetos, significações, costumes e pro- 
dução de efeitos sociais. Isso está ocorrendo desde a mídia tradicional até os novos espaços midiáticos, baseados na interação em tempo real e na possibilidade de criação de espaços artificiais ou virtuais. A partir do computador, a simulação digitalizou-se e passamos da plataforma analógica à digital, apesar da contínua interface entre os dois campos. Daí decorre a formação da cibercultura, uma cultura da simulação ou do fluxo, que faz da "representação apresentativa uma nova forma de vida” (SODRÉ, 2002, p. 17).

Essa configuração é possível de ser verificada nas redes sociais ${ }^{1}$, que promoveram novas formas de produção e difusão da informação e transformaram as relações entre linguagem e experiência, selecionando, ordenando e classificando, por meio da constituição de narrativas, determinadas realidades para o público. A partir da seleção do que será narrado, começam as escolhas e a classificação de temáticas que retêm assuntos com os quais, em princípio, o público se identifica: a política é um deles e cotidianamente ocupa lugar privilegiado na mídia, seja por meio de personagens emblemáticos, seja com denúncias e escândalos de corrupção, seja no período de eleições, entre outros.

Para além dos homens políticos, a política está unida à moral, levando sua finalidade ao estado da virtude, ou seja, a formação moral dos cidadãos e o conjunto dos meios necessários para tais fins. Esse é o conceito para Aristóteles (1973), que considera o estado uma esfera moral, condição e complemento da moral individual e fundamento essencial da suprema atividade contemplativa. A política, no entanto, se distingue da moral, porque sua relação ancora-se no indivíduo enquanto coletividade. A ética refere-se à doutrina moral individual, já a política é a doutrina moral social.

Numa época de comunicação em rede, "a vida social, as mentalidades, os valores e os processos culturais parecem definitivamente vinculados a telas, monitores e ambientes virtuais" (MORAES, 2010, p. 15) e a dimensão dessa era da imagem e de tecnologias parecem se tornar cada vez mais sinestésicas, inserindo, para além da informação, o afeto na circulação dos conteúdos. Para Muniz Sodré (2006, p. 123), diante dos registros e da aceleração retórica cada vez maior, há uma incitação à consciência "fascinada, emocionada, afetivamente mobilizada a entrar no jogo da produção e consumo dos efeitos energéticos do real".

1 Utilizamos o conceito de rede social a partir de Recuero (2009) que a define enquanto "um conjunto de dois elementos, atores (pessoas, instituições, ou grupos que seriam os nós da rede) e suas conexões (interações ou laços sociais)". 
Outra característica do novo sistema de comunicação, baseado na integração em rede digitalizada de múltiplos modos, é a capacidade de incluir e abranger diferentes expressões culturais. Em razão de sua diversidade, o sistema é capaz de abarcar múltiplas formas de expressão, bem como a variedade de interesses, valores, imaginações e conflitos. É nesse contexto, dentro do espaço das redes sociais, particularmente o Facebook ${ }^{2}$, que mistura política, mídia e afeto, que observamos como se dá a construção do que denominamos por narrativas catárticas, ou seja, relatos nos quais se evidencia uma descarga emocional do indivíduo pela estrutura enunciativa. Tais relatos incorporam elementos dramáticos e trágicos enraizados na experiência individual dos usuários dessa rede social, mas que quando circulados nessa plataforma tornam-se experiências coletivas a um só tempo, ou seja, no tempo da partilha da rede.

Assim como o conceito de política, tomamos o conceito de catarse também a partir da concepção aristotélica, cuja argumentação baseiase no fato de que algumas emoções podem ser liberadas por meio de uma descarga emocional provocada por uma situação dramática. $\mathrm{Na}$ Grécia Antiga, a catharsis era compreendida como o despertar de eleos e phobos, respectivamente piedade e temor, a partir de uma ação representativa que se daria na tragédia, enquanto processo de identificação, numa economia de afetos que resultaria em um estado de purificação do ser. Aristóteles (2003) considerava as tragédias clássicas do teatro grego como exemplos de purgação, de temor e de pesar.

Hoje, existem elementos que ecoam no cotidiano, dos quais denominamos dramas compartilhados, responsáveis por configurar uma espécie de catarse coletiva, com características semelhantes ao conceito aristotélico, mas a partir de outras performances. Há variadas relações entre os atores que configuram as narrativas catárticas nas redes sociais, conforme já demonstramos em trabalhos anteriores (REZENDE, 2012; 2013). Nesse artigo, especificamente, analisamos a experiência catártica no cenário configurado pelas manifestações políticas ${ }^{3}$ que tomaram as ruas do Brasil, principalmente a partir de junho de 2013, e inseriram as redes sociais como espaços democráticos fundamentais para a divulgação de informações sobre

2 Rede social digital lançada em 2004 por Mark Zuckerberg. Ver mais in: www.facebook.com 3 As manifestações começaram em março de 2013 quando a prefeitura de São Paulo anunciou um aumento nas tarifas dos transportes públicos da capital. De São Paulo, as manifestações tomaram vários estados em diversas cidades brasileiras. A pauta estava centrada no aumento das tarifas do transporte público, mas foi ampliada para o cenário político, numa repulsa coletiva principalmente à corrupção. 
os protestos. Nesse contexto, entre as chamadas mídias colaborativas, analisamos o perfil do movimento conhecido pela sigla Ninja Narrativas Independentes, Jornalismo e Ação, que posteriormente se tornou Ninja - Mídia/Notícias/Publicidade, no Facebook.

O método do trabalho segue a estrutura hipertextual porque os exemplos do perfil foram extraídos aleatoriamente, segundo as conexões necessárias para a análise narrativa, na medida de sua tessitura enunciativa. Isso se deve à característica do próprio meio, enquanto plataforma multimídia, que é atualizado a todo instante. Outro motivo é a própria articulação dos conceitos utilizados ao longo da pesquisa, que segue a estrutura das marcas, não necessariamente cronológicas. Por se tratar de uma pesquisa ampliada, ainda em andamento, as análises resultam, nesta etapa, de pesquisa bibliográfica e documental. A netnografia - técnica de pesquisa que analisa o comportamento dos indivíduos na Internet - também faz parte da metodologia, assim como algumas entrevistas. Como os resultados ainda não foram finalizados, optamos, nesse recorte, em um estudo exploratório do perfil em questão.

\section{A Mídia NINJA}

Do Japão feudal, a palavra ninja significa mercenário especializado em artes marciais não ortodoxas, que pode exercer funções de espionagem e infiltração; a etimologia ainda relaciona ninja a agente secreto (Dicionário Nossa Língua Portuguesa, 2013). No perfil do Facebook, a sigla NINJA refere-se a Narrativas Independentes Jornalismo e Ação e assume a postura de uma mídia alternativa e independente, realizada por qualquer cidadão/usuário da rede social, principalmente aqueles imersos nos protestos contra a corrupção e nos atos públicos promovidos por eles e por outras organizações que nasceram nas redes sociais digitais.

O perfil do NINJA no Facebook está datado do dia 27 de março de 2013, quando os protestos na maior cidade brasileira, São Paulo, contra o aumento da passagem dos transportes começaram a ganhar visibilidade nas redes sociais e a migrarem para outros estados do Brasil.

O NINJA surge a partir da rede de coletivos político-culturais denominado Fora do Eixo, que começou a se articular em 2006. ${ }^{4}$

4 “O Circuito Fora do Eixo é uma rede de trabalhos concebida por produtores culturais das regiões 
Também é responsável pela chamada POSTV, uma web tv independente com colaboradores no Brasil e no exterior, que durante as manifestações ganhou maior visibilidade, chegando à audiência de mais de 120 mil espectadores/internautas.

No perfil do NINJA no Facebook, estavam as convocações para que os correspondentes e colaboradores cobrissem os protestos em todas as regiões do país e no exterior, como exemplifica a postagem do dia 23 de junho de 2013:

"Fotógrafos, repórteres, cinegrafistas, cidadãos a fim de entrar em nossas tropas, escrevam para midianinja@gmail.com dizendo de onde são e como podem colaborar. Estamos começando a cadastrar gente do país todo. Primeiro passo na montagem de uma rede nacional de jornalismo independente antes do lançamento do nosso site. Quem anima?" (PERFIL DO NINJA NO FACEBOOK, 2013, s/n).

$\mathrm{Na}$ época das primeiras manifestações, o perfil tinha aproximadamente 74 mil curtidas e 56 mil usuários que compartilhavam e acessavam a página diariamente. Um dos participantes do perfil, Bruno Torturra (LORENZOTTI, 2013), afirma que é impossível calcular o número de colaboradores devido à característica da rede, isso porque, segundo ele, há pessoas que se dispõem a ser ninja por um dia ou apenas por horas, dependendo do contexto. No dia 20 de junho de 2013, o Ninja realizou a cobertura de protestos em 50 cidades brasileiras. Há alguns núcleos nas capitais, com aproximadamente seis (6) pessoas, cuja média de faixa etária é de 20 anos, a maior parte sem formação jornalística (LORENZOTTI, 2013).

Em junho de 2014, o número de curtidas e usuários é quatro vezes maior e o grupo conseguiu criar um site (https://ninja.oximity. com), no qual é possível encontrar, além de conteúdo, informações sobre o movimento que se define como "uma rede de comunicadores que produzem e distribuem informação em movimento, agindo e comunicando".

Apostamos na lógica colaborativa de criação e compartilhamento de conteúdos, característica da sociedade em rede, para realizar re-

centro-oeste, norte e sul em 2006. Começou com uma parceria entre produtores das cidades de Cuiabá (MT), Rio Branco (AC), Uberlândia (MG) e Londrina (PR), que queriam estimular a circulação de bandas, o intercâmbio de tecnologia de produção e o escoamento de produtos nesta rota desde então batizada de "Circuito Fora do Eixo"”. Ver mais in: http://foradoeixo.org.br/ e https://ninja.oximity.com/partner/ninja/history. 
portagens, documentários e investigações no Brasil e no mundo. Nossa pauta está onde a luta social e a articulação das transformações culturais, políticas, econômicas e ambientais se expressa. (SITE DO NINJA, 2014, s/n).

A definição utilizada pelo Ninja também menciona as mudanças possibilitadas pela Internet ao jornalismo e a distribuição de conteúdo:

Vivemos uma cultura peer-to-peer (P2P), que permite a troca de informações diretas entre as pessoas, sem a presença dos velhos intermediários. Novas tecnologias e novas aplicações têm permitido o surgimento de novos espaços para trocas, nos quais as pessoas não só recebem mas também produzem informações. Neste novo tempo, de redes conectadas às ruas, emergem os cidadãos multimídia, com capacidade de construir sua opinião e compartilhá-la no ambiente virtual. Articulados, esses novos narradores fazem a Mídia NINJA (SITE DO NINJA, 2014, s/n).

A cobertura realizada pela mídia NINJA se dá por streaming, ou seja, por fluxos de informações; também há fotógrafos que enviam material da câmera para o celular e do celular para a rede, gerando uma cobertura instantânea, à medida dos acontecimentos, na página do Facebook e também no site. No entanto, o que nos interessa nessa análise, particularmente, não é a operacionalidade da cobertura pelo grupo, ainda que seu contexto seja importante na compreensão do processo como um todo, mas a tessitura do que denominamos catarse coletiva, que, acreditamos, está relacionada a uma perspectiva do afeto, enquanto pulsão e engajamento político, numa plataforma que permite que seus usuários possuam mais liberdade de narrar e comunicar.

\footnotetext{
5 Streaming é a distribuição de conteúdo multimídia por meio da Internet. Os colaboradores se conectam com o servidor que começa a enviar os arquivos de vídeo. Quando o colaborador começa a receber o arquivo ele constrói um buffer na qual começa a salvar a informação, quando esse buffer é preenchido com uma pequena parte - conhecida como stream, o colaborador/usuário começa a executar o arquivo e vê-lo em um player enquanto simultaneamente, o download é continuado. 0 sistema opera sincronizado para que o arquivo possa ser visto enquanto se baixa, sendo que a rapidez depende da banda larga disponível para a operação. A mídia é reproduzida à medida que chega ao usuário, desde que a sua largura de banda seja suficiente para reproduzir os conteúdos em tempo real, o que permite ao usuário reproduzir conteúdos protegidos por direitos autorais, na Internet, sem a violação desses direitos, similar ao rádio ou televisão aberta. Ver mais in: ALMEIDA, Juliana. Transmissão Multimídia Multidestinatária. Disponível em: <http://www.gta.ufrj.br/grad/01_2/vidconf/inicial.html>. Acesso em: 12 maio 2010.
} 


\section{A catarse coletiva (ou) o engajamento político por meio do afeto}

Do latim, affectus ou adfectus, é um conceito utilizado na filosofia para designar um estado da alma, um sentimento. A definição de Spinoza, na Ética III, associa o afeto à transformação que ocorre simultaneamente no corpo e na alma e afirma que a forma como somos afetados pode diminuir ou aumentar nossa vontade de agir. Para Spinoza (2013), o mundo exterior aparece em um contexto que pode diminuir ou aumentar o conatus de cada um, o qual é a essência do corpo e do espírito. O conatus é uma força interna positiva ou afirmativa, responsável por preservar a existência dos sujeitos, que possuiria uma duração ilimitada até que causas exteriores mais fortes e mais poderosas o destruam. O conatus, cuja referência é a alma e o corpo, é o apetite do homem, já o desejo é o apetite acompanhado de consciência. Segundo Negri, "não há, portanto, nenhuma diferença entre o apetite e o desejo, exceto que o desejo se refere em geral aos homens quando têm consciência de seu apetite, e por isso pode ser definido assim: o desejo é o apetite com consciência de si mesmo" (NEGRI, 1993, p. 185). É nesse sentido que compreendemos, a partir de Spinoza (2013), que a relação originária da alma com o corpo e com o mundo é a relação afetiva: o afeto enquanto afetação e afetividade, pois a essência do homem é o desejo, a consciência de que, no corpo, é apetite.

Compreendendo o conceito de afeto, acreditamos que os relatos construídos pelos usuários no perfil do grupo NINJA são movidos por uma potência sensível que se desenha no emaranhado narrativo, configurado por grande parte dos enunciados, numa experiência catártica, mas gerenciada pela configuração dos afetos enquanto força motriz.

Sodré (2006, p. 28-29) explica que termos como afeição ou afecção, provenientes de affectus e afectio, referem-se a um conjunto de estados que atua na função psíquica chamada de afetividade, já afeto, com a mesma etimologia, refere-se ao exercício de uma ação em particular sobre a sensibilidade de determinado ator, que necessariamente é um ser vivo. Lembra o autor que a ação de afetar, no latim clássico, contém o significado de emoção, na medida em que corresponde a commuovere. Comporta, nesse sentido, um fenômeno afetivo que se define por um estado de choque ou de perturbação na consciência. Desta forma, Sodré (2006) afirma que afeto pode 
equivaler à ideia de energia psíquica, "mostra-se, assim, no desejo, na vontade, na disposição psíquica do indivíduo que, em busca de prazer, é provocado pela descarga de tensão" (SODRÉ, 2006, p. 29).

Percebemos "essa descarga emotiva" nos relatos do coletivo NINJA, que se configuram também como táticas estéticas porque comportam uma exaltação fanática legitimada pela dimensão sensível apresentada por convicções próprias, que podem ser visões e perspectivas do mundo e posições marcadas sobre sentimentos. Também são artifícios de discurso, recorrentes no passado, no âmbito do uso racionalista do afeto pela retórica, que se caracterizava como a arte da expressão e da persuasão, servindo para convencer, no sentido racionalista do termo o que, para Sodré (2006), indica seu aspecto afetivo ou irracional e, desta forma, serve para comunicar ideias e emoções, produzindo sensações.

A informação, a comunicação e a imagem, com todas suas tecnologias nos permitem viver imersos em experiências cada vez mais sensíveis, na medida em que lançam os sujeitos em paisagens que relacionam jogos de identificação, de projeção e de espelho. Desta forma, são sujeitos que se identificam, que verificam naquela realidade a sua própria vida ou ainda se colocam no lugar do outro (porque, por vezes, o sujeito se reconhece também naquilo em que ele não está, no quadro em que atua como excluído).

A situação enunciativa que se estabelece não dá conta de uma racionalidade linguística, nem a partir de lógicas argumentativas da comunicação, mas ocorre, desta forma, numa espécie de política de afetos a partir do que Sodré (2006, p. 10) designa pela configuração de estratégias sensíveis, que se referem "aos jogos de vinculação dos atos discursivos às relações de localização e afetação dos sujeitos” no interior dessa rede, como destacamos no exemplo a seguir: 


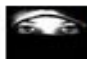

NINUA

Sexta próximo a Belo Horizonte

Na noite de ontem faleceu o jovem Luis Felipe Aniceto de Almeida que caiu do viaduto durante as manifestações do dia 22 de julho, em Belo Horizonte.

O jovem caiu do viaduto José de Alencar ao fugir dos ataques de bombas de gás lacrimogêneo e balas de borracha. Essa é a segunda morte decorrente dos conflitos. No último dia 30 Douglas Henrique também faleceu ao cair do mesmo viaduto.

Uma das reivindicações da Assembleia Popular Horizontal de Belo Horizonte para o prefeito Márcio Lacerda é a renomeação do viaduto para Douglas Henrique e exigência à responsabilização da polícia e do Estado pelas mortes.

Curtir - Comentar - Compartilhar

13 466 pessoas curtiram isso.

Principais comentários -

Escreva um comentário...

Camo curtir uma coisa destas? Revoltante.

Curtir - Responder - @38 - Sexta às 13:03

(5) 3 Respostas

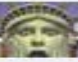

jovem

Luz,Paz e meus sentimentos a familia desse

Curtir - Responder * 37 - Sexta às 12:57

Figura 1. Exemplo de relato sobre a morte de um manifestante durante protesto.

Fonte: Print da autora, 2014.

Conforme podemos observar na figura 1, o post do NINJA anuncia a morte de um manifestante em um protesto na cidade de Belo Horizonte, estado de Minas Gerais, sudeste do Brasil. O anúncio da morte, enquanto estrutura narrativa, se apresenta de forma descritiva e sem adjetivos, mas os relatos que se constroem abaixo, nos comentários do post em questão, desenvolvem um emaranhado cartático, como podemos verificar na figura 2 : 


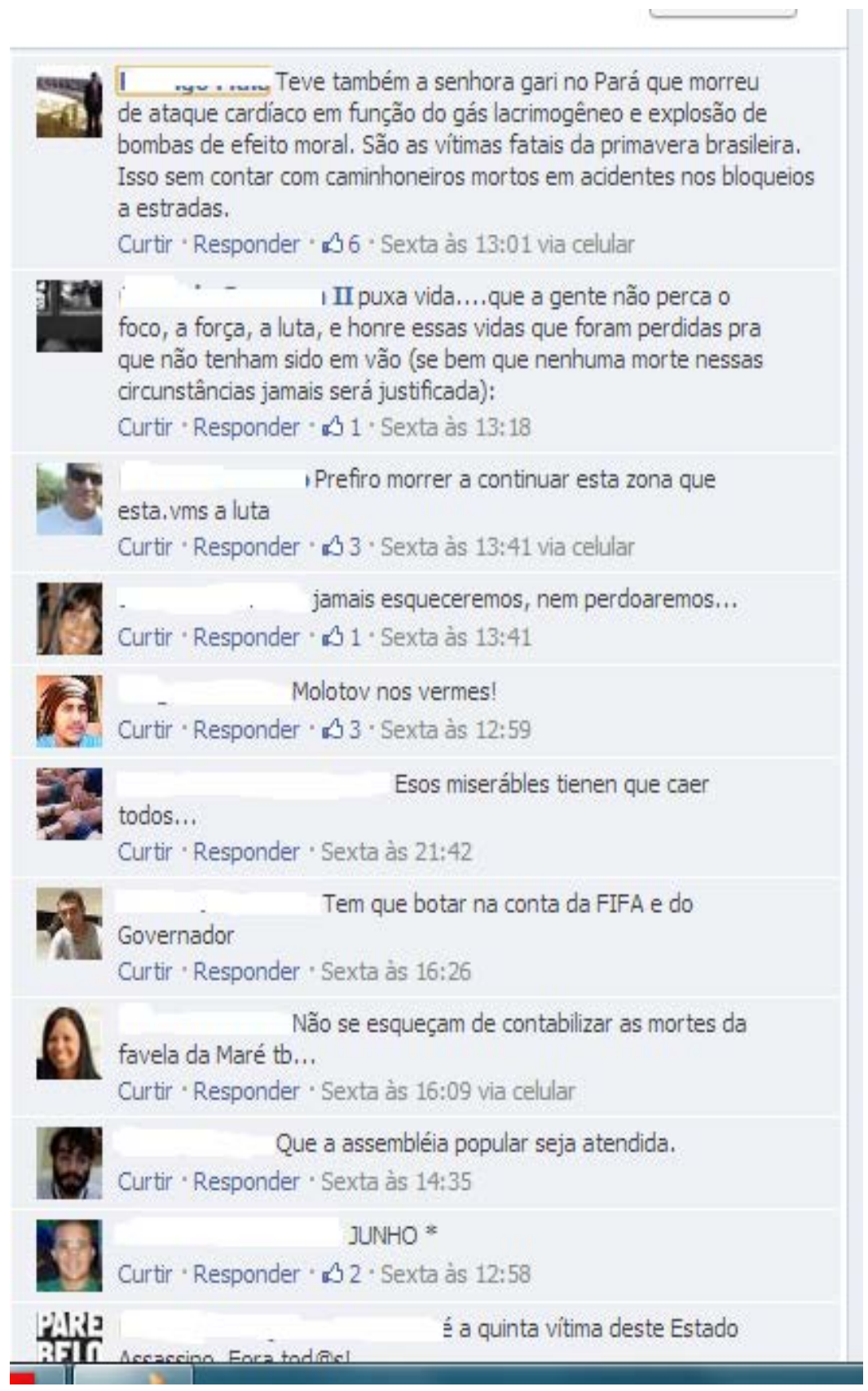

Figura 2. Comentários do post da figura 1. Fonte: Print da autora, 2014. 
Além de algumas lamentações sobre o fato, os usuários se colocam afetivamente na narrativa, utilizando também a liberação emocional pertencente ao próprio conceito de catarse, como é o caso do relato "jamais esqueceremos, nem perdoaremos..."; "Molotov nos vermes" (sic); "Tem que botar na conta da Fifa e do Governador (sic)" e "Prefiro morrer a continuar nesta zona que esta. vms a luta" (sic), como verificamos na figura 2.

A liberação emocional, na qual a catarse está ancorada, não ocorre apenas pelo drama em questão (a morte do manifestante), mas pela memória ativada, por meio da recordação de eventos (dos protestos como um todo, anteriores, mas também pela configuração histórica própria do país), resultando numa enxurrada de expressões emotivas. Para a psicanálise, trata-se de um método em que o efeito objetivado é a purgação (catharsis), uma "descarga" dos afetos ligados aos acontecimentos trágicos, num desejo de indignação, superação e/ou esquecimento, ou seja, uma descarga emocional na qual se libera, no sujeito, satisfações substitutivas.

As reminiscências podem ser provocadas de diferentes formas e geralmente se dá por meio do processo de análise em que o sujeito ressignifica a emoção através da fala (aqui da narrativa), representando a situação vivida anteriormente. No contexto do perfil NINJA no Facebook, a partir dos fragmentos verificados, notamos que esses espaços constituem uma espécie de locus de atualização dos afetos, que posteriormente saíram da rede e ganharam as ruas, nas manifestações em todo Brasil. É como se sujeitos encontrassem naquele espaço um local para além do acontecimento enquanto notícia, no qual é possível também despejar sua indignação com o cenário político e, em alguns casos, realizar uma espécie de análise de si e dos outros a partir do diálogo com os demais participantes da rede, numa espécie de política de afetos, como podemos observar nos relatos abaixo, detalhadamente na figura 3.

"Filhos da puta! Agora não pode nem mais gritar na rua alheia que incomoda?? Muda de país então seus políticos de merda! (sic)

"claro que não podemos deixar esse políticos safados dormir temos que gritar mesmo e procurar nossos direitos Brasil está uma merda por causa de pessoas como você que se calam mais não mais o Brasil acordo só você está alienado ainda (sic). 
Filhos da suta! Agora nao pote nem mas çriter na rua ahea que ncomoda?? Muda de pais entao seus pcliticos de merda!

Curtir · Ressorder ' $\boldsymbol{B}^{3} 100$ ' há 21 horas via ceular

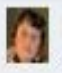

Na real de madrugada fãc pode nesmc...

hehe

Curtir ' an 4 ' há 21 horas ' Editajo

d.

claro que pode nzัo jocemos deixar esse

pol'ticos safajos domir tenos que gitar mesmo e procurar nossos direitos Erasi esta uma merda prr causa ce pessoas como você cue se calam nais nềo mais o Erasil acordo só você esta alienado ainda

Curtir ' n 12 ' há 21 horas

Na boa, até aqui apoiei 0

Movimento. Mas, por que a Maníestação em frerte o Palace?

Por que atrapallar a feste dos outros? Podem me explicar?

Queria sajer o cue houve.

Agora parem de gr tar contra burguesia, pois a maicr parte dos jovens pensentes desse rovinento tambén é bưguês. A culpa do pais está assim rão é da burguesia.

Ser rio não é crmee nem perado.

Crime é a truzulência da PM. Pecado é a scberba do Cabrale as mentiras da Dilma, e as Nctas Fiscais frias do Renan.

Querenos um Estaco Democrático de Direio e Laco!

Curtir ' R' 9 - há 18 horas

9

pagando de burro, nac saje de quen era o casamerto, e

burgues com 2 bilhao na conta não ta certo nẫo rapaz, vc acha

que o Jaratas conseguiu isso cono? conxavos politios!

se fosse vc casando a MMiria deixar os manifestante te atecarem mas ja o baatao, ele é protejido, snceranente, vc falou nta asneira, $\$ 0 \mathrm{pq}$ tal individuo nâo é miltar e nem politico, ele é imure a acusaz̧oes de podres feitos felo mesmo? acho que não, eu pelo menos...

refita mais meu :aro

Curtir ' 43 - há 17 horas

Figura 3. Exemplo de diálogo entre os usuários. Fonte: Print da autora, 2014. 
A narrativa exaltada, com xingamentos, palavras de ordem e agressão verbal, inclusive a outros usuários desse mesmo espaço, aponta para uma configuração na qual a ação consiste em se apropriar de todas as causas exteriores que aumentam o poder do conatus, ou seja, da força interna positiva. A ação trata-se de uma potência, a paixão (pathos). Por outro lado, segundo Spinoza (2013), tanto a ação quanto a paixão se dão em termos de causa adequada, mas também de causa inadequada e o homem livre é aquele que não se deixa vencer pelo exterior, mas sabe dominá-lo. É nesse contexto que Spinoza define a essência humana pelo desejo, ou, segundo Chauí (1979, p. 20), "o desejo é a tendência interna do conatus em fazer algo que conserve ou aumente sua força”.

As ideias das afecções, enquanto modos do atributo do pensamento, quando exercem apenas representações, se tornam, muitas vezes, experiências dispersas e sem sentido. Tais ideias são modificações da vida e de uma potência do corpo, fundadas no interesse vital que, ancoradas em uma força de pertencimento faz o corpo mover-se (afetar e ser afetado por outros corpos). Mesmo nesses deslocamentos narrativos, a virtude dessas ações é poder afetar outros corpos e poder ser por eles afetado, não importa a forma, pois o corpo (aqui representado pelo perfil de cada usuário dessa rede) é um indivíduo que se define tanto pelas relações internas como na interação com os demais corpos (outros perfis), sendo por eles alimentados, revitalizados e fazendo o mesmo em troca.

\section{Considerações finais}

Os relatos incorporam elementos enraizados na experiência individual dos usuários do NINJA, mas que quando circulados nessa plataforma tornam-se experiências coletivas a um só tempo, ou seja, no tempo da partilha no interior dessa rede, que fornece significado e amplia o coletivo como esfera discursiva, podendo operacionalizar, inclusive, embates narrativos fora da ambiência da rede, como evidenciamos posteriormente nas manifestações que tomaram as ruas do Brasil.

Trata-se de um campo de operações singulares, mas que oferecem um reconhecimento tal e qual produzem para os demais atores que compartilham esses relatos. A estratégia configura-se, segundo Sodré (2006, p. 11) como "eustochia, clássica designação grega para 
a mirada justa sobre uma situação problemática, convocada pela potência sensível do sujeito". O significado em potência é um afeto que irrompe num aqui e agora. "As experiências sensíveis podem orientar-se por estratégias espontâneas de ajustamento e contato nas situações interativas, mas salvaguardando sempre para o indivíduo um lugar exterior aos atos puramente linguísticos, o lugar singularíssimo do afeto" (SODRÉ, 2006, p. 11).

A tessitura narrativa que se configura é predominantemente mais voltada para as expectativas do público, mas se relacionam também a uma gama de recursos simbólicos aplicados nas manifestações e protestos que pertencem a uma lógica espetacular, isto é, da encenação suscetível de cativar os participantes, e também usuários daquela rede (ou do próprio perfil), numa espécie de jogo, cuja emoção é o elemento central e os afetos, a força motriz. Nesse sentido, as redes sociais também se constituem enquanto espaços de catarse, onde os usuários podem se expressar com mais liberdade, expor seus anseios, despejar seus sentimentos na tentativa de sobreviver as decepções inevitáveis do cotidiano.

Para Castells (1999), a inclusão da maior parte das expressões culturais no sistema de comunicação integrado, como a Internet (baseado na produção, distribuição e intercâmbio de sinais eletrônicos digitais), tem consequências importantes para os processos sociais. Primeiramente porque enfraquece consideravelmente o poder simbólico dos emissores tradicionais e hegemônicos e depois porque transforma o espaço e o tempo, dimensões fundamentais da vida.

$\mathrm{Na}$ medida em que os sujeitos são solicitados a viverem no interior de ambientes tecnocomunicacionais como as redes sociais digitais, onde a interatividade e a conectividade são permanentes, a mídia torna-se possibilidade de um espaço autônomo e privilegiado. Fatos e coisas passam a ser reapresentados a partir de um tempo vivo e escritos por grande parte de seus usuários, os quais anteriormente estavam situados apenas como espectadores de tais narrativas.

Em um mundo de fluxos de poder, onde a maior parte das informações são distribuídas pelos grupos hegemônicos das grandes corporações midiáticas e no qual o espaço para protestar ainda é muito limitado, cada vez mais pessoas se organizam ao redor de redes sociais que conectam indivíduos e grupos, conforme a realização dos objetivos processados, e de decisões que podem ser tor- 
nar estratégicas e fazer a diferença no processo de consolidação da democracia. Tal é o exemplo do coletivo NINJA.

No cenário contemporâneo, do avanço do capitalismo e da descrença da política como estrutura de organização da vida coletiva, em meio às inúmeras mudanças, por vezes confusas e incontroláveis que as tecnologias de informação e de comunicação promovem, tais agrupamentos coletivos, como os configurados nas redes sociais, se tornam agentes transformadores do cotidiano pela batalha discursiva. A luta pela palavra também se estabelece pelo processo catártico, ainda que tais relações se criem cada vez mais na esfera virtual como as redes socias digitais, é preciso lembrar que há dias em que "as redes invadem as ruas".

\section{Referências}

ALMEIDA, Juliana. Transmissão Multimídia Multidestinatária. [online] Disponível em:

<http://www.gta.ufrj.br/grad/01_2/vidconf/inicial.html> Acesso em: 12 maio 2013.

ARISTÓTELES. (1973). Obras. Madeira: Ed. Aguilar. Segunda Edição. . (2003). Arte poética. São Paulo: Ed. Martin Claret.

CASTELLS. (1999). Manuel. A sociedade em rede. São Paulo: Paz e Terra.

CHAUÍ, Marilena. (1979). Espinoza: vida e obra. In: Espinoza. São Paulo: Abril Cultural.

DICIONÁRIO NOSSA LÍNGUA PORTUGUESA. [online] Disponível em: <http://nossalinguaportuguesa.com.br/dicionario/ninja/> Acesso em: 25 jun.2013.

LORENZOTTI, Elizabeth. POSTV, de pós-jornalistas para pós-telespectadores. [online] Disponível em: site do Observatório da Imprensa. $<$ http://www.observatoriodaimprensa.com.br/news/view/postv_de_pos_jornalistas_para_pos_telespectadores>. Acesso em: 25 jun. 2013. 
MORAES, Dênis. Mutações do visível: Da comunicação de massa à comunicação em rede. Rio de Janeiro, Pão e Rosas, 2010.

NEGRI, Antonio. (1993) A anomalia selvagem: poder e potência em Spinoza. Rio de Janeiro: Editora 34.

NINJA. Perfil do Facebook [online]. Disponível em: <https://www.facebook.com/midiaNINJA>. Acesso em: 23 jun.2014.

NINJA. Site. [online]. <Disponível em: https://ninja.oximity.com/ > Acesso em: 23 jun.2014.

RECUERO, Raquel (2009). Redes Sociais na Internet. Porto Alegre, Sulina.

REZENDE, Renata (2012). Dramas compartilhados: as redes sociais como espaços de catarse e a política dos afetos. In: Anais do XXXV Congresso Brasileiro de Ciências da Comunicação - Intercom, 35, 2012, Fortaleza.

(2013). A mídia ninja e o espaço da catarse coletiva. In: Anais do XXXVI Congresso Brasileiro de Ciências da Comunicação - Intercom, 36, 2013, Manaus.

SODRÉ, Muniz. (2002). Antropológica do Espelho: uma teoria da comunicação linear e em rede. Petrópolis: Vozes.

Petrópolis, Vozes.

(2006). As estratégias sensíveis: afeto, mídia e política.

SPINOZA. (2013). Ética. São Paulo: Autêntica, segunda edição. 